\title{
PENGUATAN NILAI BUDI PEKERTI MELALUI TRADISI RASULAN GUNUNGKIDUL
}

\author{
Ervina Wulandari, Annisa Fitri Nurkholidah, Cahyani Solikhah ${ }^{1}$
}

\begin{abstract}
Abstrak
Artikel ini bertujuan untuk mengetahui dan memahami penguatan nilai-nilai budi pekerti melalui sosialisasi masyarakat khususnya melalui tradisi Rasulan di Dusun Tegalmulyo, Desa Kepek, Wonosari dan Dusun Jambu, Desa Plajan, Saptosari, Gunungkidul. Penguatan budi pekerti dalam masyarakat dapat terwujud melalui tradisi yang ada dalam masyarakat itu sendiri. Uniknya, semua masyarakat dapat mempraktikkan nilai-nilai yang terkandung dalam tradisi Rasulan yang telah ada sejak dulu hingga sekarang. Penelitian ini menggunakan metode kualitatif deskriptif dengan teknik observasi, wawancara, dan studi pustaka. Dari penelitian yang dilakukan dapat diperoleh hasil bahwa penguatan budi pekerti telah ditanamkan sejak kecil dengan mengenalkan tradisi Rasulan kepada masing-masing individu. Keikhlasan, bersyukur, tanggung jawab, toleransi, dan gotong royong menjadi nilai-nilai yang diajarkan secara tidak langsung melalui serangkaian tradisi Rasulan yang diadakan dalam masyarakat tersebut. Media dalam proses penguatan nilai-nilai budi pekerti yaitu dengan menggunakan perlengkapan tradisi Rasulan yang berupa simbol dan memiliki makna. Pengenalan nilai-nilai tersebut tidak hanya diperuntukkan bagi masyarakat tertentu saja melainkan untuk masyarakat umum, baik muda maupun tua.

Kata kunci: budi pekerti, nilai, Rasulan, sosialisasi, tradisi
\end{abstract}

\footnotetext{
${ }^{1}$ Mahasiswa Pendidikan Sosiologi, Universitas Negeri Yogyakarta, (ervina.wulandari298@gmail.com)
} 


\section{PENDAHULUAN}

Pendidikan bagi setiap individu tidak hanya diperoleh dari bangku sekolah formal saja. Namun dari berbagai kehidupan sehari-hari merupakan sebuh praktik pendidikan (Butet, Seminar Nasional konstektualisasi Pendidikan Adat di Universitas Negeri Malang). Dari pernyataan tersebut, pendidikan dapat diperoleh dari kegiatan dan kebiasaan suatu masyarakat. Pendidikan dapat berlangsung di lingkungan keluarga, masyarakat dan sekolah. Pendidikan di keluarga disebut pendidikan informal, pendidikan di masyarakat disebut pendidikan non-formal dan pendidikan di sekolah disebut pendidikan formal. Dalam perundang-undangan, pendidikan dalam keluarga merupakan bagian dari jalur pendidikan luar sekolah, yang lebih menekankan kepada penanaman keyakinan keagamaan, nilai budaya, nilai moral dan keterampilan.

Pendidikan formal adalah pendidikan yang ditempuh pada lembaga legal dan tahapan dalam pendidikan ini sangat jelas. Dalam pendidikan formal, peserta didik harus menempuh pendidikan dasar yang memiliki durasi waktu selama sembilan tahun, selanjutnya ke tingkat SMA atau SMK, setelah itu perguruan tinggi. Sedangkan pendidikan informal dilakukan secara mandiri dari dalam diri sendiri yang memiliki kesadaran tanggung jawab yang penuh dalam proses penerapannya. Pendidikan informal biasanya dimulai dari lingkungan keluarga serta lingkungan masyarakat. Dalam lingkungan keluarga orang tua memiliki peran penting karena orang tua merupakan panutan pertama yang dijadikan teladan. Selanjutnya lingkungan masyarakat juga tidak kalah penting dengan perannya sebagai penunjang pembentukan karakter seseorang. Jika lingkungan masyarakat tidak memiliki perilaku yang baik dikhawatirkan akan memiliki dampak yang buruk dalam perkembangan material seseorang.

Pendidikan memiliki dua fungsi, yaitu fungsi manifes dan fungsi laten. Fungsi manifes (nyata) dari pendidikan adalah mengembangkan bakat perseorangan demi kepuasan pribadi dan untuk kepentingan masyarakat. Kepentingan masyarakat diantaranya untuk melestarikan kebudayaan yang ada di masyarakat tersebut karena pendidikan akan mengubah pola pikir masyarakat untuk tetap menjaga dan melestarikan kebudyaan yang dimilikinya. Fungsi lain dari pendidikan adalah fungsi laten (tidak nyata) adalah mengurangi pengendalian orang tua terhadap anak-anaknya. Melalui pendidikan sekolah, orang tua melimpahkan tugas serta wewenangnya dalam mendidik anak kepada pihak sekolah. Dengan begitu, anak akan mendapatkan pengajaran dari orang tua dan 
sekolah. Selain itu, harapannya adalah anak tidak berperilaku menyimpang.

Fungsi pendidikan nasional berdasarkan Pancasila dan UUD Tahun 1945 adalah mengembangkan kemampuan dan membentuk watak serta peradaban bangsa yang bermanfaat dalam rangka mencerdaskan kehidupan bangsa, bertujuan untuk mengembangkan potensi peserta didik agar menjadi manusia yang beriman dan bertaqwa, berakhlak mulia, sehat, berilmu, cakap, kreatif, mandiri dan menjadi warga negara yang demokratis serta bertanggung jawab. Untuk mengemban fungsi tersebut, pemerintah menyelenggarakan suatu sistem pendidikan nasional sebagaimana tercantum dalam UU No 20 tahun 2003, tentang Sisdiknas.

Kusuma (melalui Suryani, 2015:3-5) menegaskan bahwa pendidikan karakter merupakan bentuk kegiatan manusia yang di dalamnya terdapat suatu tindakan yang mendidik dan diperuntukkan bagi generasi selanjutnya. Tujuan pendidikan karakter adalah untuk membentuk penyempurnaan diri individu secara terus-menerus dan melatih kemampuan diri demi menuju kearah hidup yang lebih baik. Pendidikan karakter ini membawa peserta didik ke pengenalan nilai secara kognitif, penghayatan nilai secara afektif, dan akhirnya ke pengamalan nilai secara nyata. Inilah rancangan pendidikan karakter (moral) yang oleh Lickona (1991: 51) disebut moral knowing, moral feeling, dan moral action. Atas dasar rancangan tersebut, semua mata pelajaran yang dipelajari oleh peserta didik di sekolah harus bermuatan pendidikan karakter yang bisa membawanya menjadi manusia yang berkarakter seperti yang ditegaskan oleh Lickona tersebut (Suryani, 2015).

Pada hakikatnya, pendidikan karakter merupakan suatu sistem pendidikan yang berupaya menanamkan nilai-nilai luhur kepada warga sekolah yang meliputi komponen pengetahuan, kesadaran atau kemauan, dan tindakan untuk melaksanakan nilai-nilai tersebut. Dalam membangun karakter budaya bangsa, lingkungan pendidikan harus mengarah pada penciptaan lingkungan keluarga yang sarat dengan nilai (agama, budaya, dan kebangsaan). Budaya merupakan sebuah kebiasaan yag dilakukan secara berulang-ulang di dalam masyarakat tersebut, yaitu sebagai hasil cipta, karsa, karya, dalam masyarakat.

$$
\text { Lickona dalam Puspitasari }
$$
mengatakan bahwa karakter mengalami pertumbuhan yang membuat suatu nilai menjadi budi pekerti, sebuah watak batin yang digunakan dalam merespon situasi melalui cara dengan moral. Karakter berkaitan dengan berbagai hal yang dipelajari melalui pengalaman, pelatihan atau proses sosialisasi. Sehingga nilai-nilai baik yang dimiliki individu 
akan menunjukkan perilaku karakter individu tersebut.

Indonesia terdiri dari beragam suku bangsa yang memiliki bermacam kebudayaan. Kebudayaan-kebudayaan tersebut memiliki nilai-nilai filosofis yang dapat digunakan menjadi pedoman bagi masyarakat untuk menjalani kehidupannya bersama masyarakat. Kadang, di suatu masyarakat terdapat suatu acara kebudayaan yang dilakukan secara rutin. Sehingga timbul usaha yang bertujuan untuk melaksanakan acara tersebut yang memiliki nilai filosofis tertentu dalam masyarakat itu sendiri, misalnya adalah Galungan dan Kuningan yang rutin dilaksanakan pada masyarakat Bali.

Telah menjadi rahasia umum bahwa Yogyakarta dikenal sebagai kota budaya karena masyarakatnya melestarikan kebudayaan yang ada. Sehingga kebudayaan-keudayaan yang ada di Yogyakarta masih kental dan menjadi salah satu obyek wisata andalan baik bagi wisatawan domestik maupun wisatawan mancanegara. Salah tradisi yang masih kental adalah Rasulan yang terdapat di Gunungkidul. Tradisi ini sudah ada sejak dulu dan tetap dilaksanakan sampai sekarang. Tradisi Rasulan ini memiliki berbagai nilai-nilai dalam masyarakat yang digunakan sebagai pedoman dalam menjalankan kehidupan bermasyarakat. Sehingga dalam hal ini akan dijelaskan mengenai penguatan nilai yang terdapat dalam masyarakat Gunungkidul melalui tradisi rasulan.

\section{METODELOGI}

Penelitian ini menggunakan metode kualitatif deskriptif dengan teknik wawancara, observasi, dan studi pustaka. Teknik wawancara dilakukan kepada informan yang dipilih melalui purposive sampling atau sampel bertujuan. Dalam hal ini, wawancara ditujukan kepada masyarakat yang memahami dengan jelas mengenai tradisi rasulan. Selanjutnya, observasi bertujuan untuk memahami dan mengetahui bagaimana antusiasme masyarakat dalam mengikuti tradisi Rasulan. Penelitian ini dilaksanakan pada bulan Agustus hingga Oktober 2017 di Dusun Tegalmulyo, Desa Kepek, Wonosari dan Dusun Jambu, Desa Plajan, Saptosari, Gunungkidul. Data yang telah diperoleh kemudian dianalisis dengan menggunakan model interaktif dari Miles dan Huberman berupa reduksi data, penyajian, dan penarikan kesimpulan atau verifikasi. 


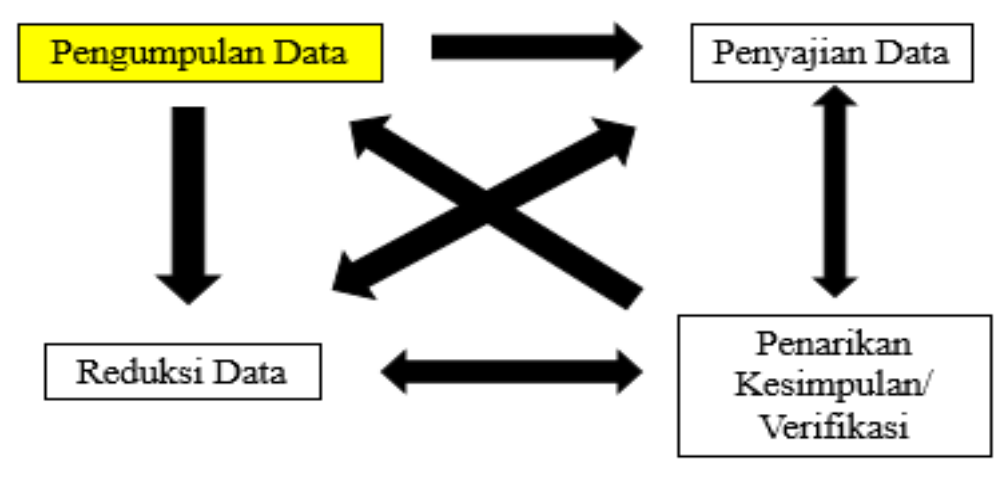

Gambar 1. Komponen-komponen Analisis Data Model Interaktif

\section{HASIL}

Tradisi rasulan atau bersih desa adalah salah satu seni budaya yang sudah berlangsung turun temurun. Budaya rasulan adalah termasuk budaya Jawa khususnya di wilayah Gunungkidul. Pada tiap-tiap dusun, rasulan diadakan pada waktu yang berbeda-beda (Mixdam, 2015: 17). Latar belakang munculnya tradisi Rasulan di Desa Kepek, Wonosari, Gunungkidul yaitu dulu masyarakat petani ketika masa panen memperoleh hasil yang melimpah. Sehingga masyarakat petani mengadakan syukuran yang dulu masih sederhana hanya dengan makan bersama. Hal tersebut sebagai ungkapan rasa syukur kepada Tuhan atas segala nikmat yang telah diberikan. Tradisi rasulan ini diadakan setiap satu tahun sekali, yang dalam pelaksanaannya juga berkembang, tidak hanya dengan makan bersama. Perkembangan yang terjadi adalah terdapat rangkaian kegiatan dalam tradisi rasulan seperti lomba-lomba dan hiburan bagi masyarakat. Seperti yang diungkapkan Candra Bagus Sultan Mixdam (2015: 17) bahwa dalam suasana rasulan akan dipentaskan tontonantontonan yang meriah. Dalam mengisi kegiatan rasulan biasanya juga dipertunjukkan berbagai macam pentas kesenian tradisional mulai dari reog, doger, ketoprak, wayang kulit, kirab budaya, gunungan dan juga untuk kegiatan olahraga seperti bola volly dan sepakbola.

Sedangkan di Dusun Jambu, Plajan, Saptosari, Gunungkidul terdapat cerita yang melatarbelakangi munculnya tradisi rasulan. Awalnya nenek moyang pada 
zaman dahulu membangun kebun dan rumah di dusun Sinthok. Ketika membangun kebun dan rumah tersebut diberi keselamatan dan ketentraman oleh mbaurekso (yang berkuasa). Karena keselamatan dan ketentraman yang telah diberikan, maka diadakan rasulan setiap satu tahun sekali yang artinya diadakan slametan sebagai wujud syukur. Rasulan diadakan pada hari Senin Pon setiap satu tahun sekali. Hal ini terjadi karena pemilik rumah tersebut pertama kali menempatinya pada hari tersebut. Sehingga sampai saat ini setiap satu tahun sekali pada hari Senin Pon diadakan tradisi rasulan. Tradisi rasulan diadakan supaya oleh mbaurekso (yang berkuasa) diberi keselamatan, ketentraman, kesehatan, rezeki yang lancar sampai anak cucu. Menurut kepercayaan masyarakat di dusun Jambu, apabila tidak mengadakan rasulan maka akan ada akibatnya yaitu terdapat orang yang sakit dan meninggal.

Meskipun latar belakang tradisi rasulan di dua tempat tersebut berbeda, terdapat persamaan tujuan yang dimiliki dengan adanya tradisi Rasulan. Sebagai sarana untuk menyampaikan rasa syukur merupakan salah satu yang dimiliki dalam pelaksanaan tradisi Rasulan. Uniknya, meskipun ditengah perkembangan zaman yang terjadi, masyarakat tetap melaksanakan tradisi Rasulan secara turun-temurun dan tidak ada masyarakat yang ingin menghilangkan tradisi tersebut. Adanya pewarisan kebudayaan Rasulan dari para sesepuh setempat kepada generasi baru memberikan peran penting. Sehingga, tradisi Rasulan dapat dinikmati masyarakat setiap tahunnya.

Pewarisan tradisi rasulan yang terdapat di Gunungkidul dilakukan oleh para generasi tua kepada generasi selanjutnya. Sehingga, meskipun kini dalam era modernisasi, tradisi Rasulan masih menjadi tradisi yang dijunjung oleh masyarakat Gunungkidul beserta pemerintah setempat menjadi agenda tahunan. Selain adanya pemerintah memberikan fasilitas, sosialisasi menjadikan tradisi rasulan dilaksanakan setiap tahunnya.

Sosialisasi adalah sebuah proses menyampaikan suatu hal kepada orang atau individu lain dengan tujuan untuk mempengaruhi supaya individu lain tersebut mengikuti apa yang disosialisasikan. Dalam sosialisasi biasanya menanamkan nilai-nilai yang 
sesuai dengan apa yang ada di dalam kelompok. Hal itu dilakukan dengan tujuan nilai-nilai tersebut tidak hilang dari sebuah kelompok itu. (Mixdam, 2015: 59).

Tradisi Rasulan diwariskan secara turun-temurun karena telah ditanamkan sejak kecil. Peran keluarga tidak terlepas dari masih terlaksananya tradisi rasulan hingga sampai saat ini. Kelurga ikut serta mengajar dan mengajak anak-anaknya untuk ikut melaksanakan Rasulan. Mereka diajak dalam rangkaian kegiatan rasulan, misalnya adalah mengikuti kirab budaya dan kirab gunungan. Selain itu, melibatkan para remaja yang bergabung pada kelompok karang taruna sebagai panitia.

"Tradisi ini kami tanamkan kepada anak-anak sejak kecil. Anak-anak muda dari karang taruna kami libatkan juga sebagai panitia, kemudian sekarang ini kan meneruskan tradisi yang ada sejak zaman dahulu, maka sampai besok tetep dilestarikan (Darsono/9/September/2017)'”.

Selain itu, pemerintah memberikan sumbangan yang cukup besar terhadap pelaksanaan tradisi Rasulan di Gunungkidul, baik pemerintah desa maupun pemerintah kabupaten. Misalnya adalah memberikan pengarahan ketika ada pertemuan RT untuk menyosialisasikan mengenai kebudayaan yang ada, khususnya Rasulan. Hal ini diutarakan oleh Penasihat Dukuh Tegalmulyo, Desa Kepek, Wonosari.

"Pemerintah desa kerap kali memberikan sosialisasi pertemuan $R T$ dengan memberikan pengarahan kepada orang tua nya dulu untuk menyosialisasikan kepada putra putrinya. Selain itu dengan mengajak pemuda untuk turut serta dalam kepanitiaan. Selain itu, generasi muda diikutsertakan dalam kepanitiaan rasulan, sehingga mulai sejak dini mereka sudah mengenal apa itu arti penting rasulan. (Mardiyanto/9/September/2017)".

Terciptanya masyarakat yang kompak dalam pelaksanaan tradisi Rasulan adalah karena adanya solidaritas yang kuat antar masyarakat. Ditandai dengan saling mengingatkan dan berbagi informasi mengenai tradisi Rasulan antara masyarakat asli maupun pendatang. Sosialisasi yang dilakukan tidak keras, melainkan memberikan kebebasan bagi masyarakat pendatang untuk mengikuti tradisi tersebut atau tidak.

Rasulan yang menjadi agenda tahunan di Gunungkidul mendapatkan partisipasi yang besar dari 
masyarakatnya. Hal ini ditandai dengan banyaknya masyarakat yang sepakat untuk tetap melestarikan tradisi Rasulan. Masyarakat baik tua maupun muda bekerja sama dalam menyukseskan kegiatan tersebut. Dari pengadaan biaya, gunungan, dan berbagai perlengkapan kegiatan mereka bersama-sama untuk mewujudkannya. Bukan hanya masyarakat pada dusun atau tempat kegiatan diadakannya Rasulan saja, melainkan masyarakat dari sekitar desa tersebut juga ikut berpartisipasi. Sehingga dengan banyaknya partisipasi masyarakat, menggambarkan sosialisasi yang dilihat dari kondisi masyarakat yang tetap mengharapkan tradisi Rasulan tetap diadakan dan jangan sampai punah.

Menurut Mardiyanto, tadisi Rasulan merupakan suatu tradisi yang dibutuhkan oleh masarakat secara umum. Rasulan menjadi pengikat perbedaan-perbedaan yang ada dalam masyarakat. Sehingga masyarakat sadar untuk tetap melaksanakan tradisi tersebut. Seperti yang diungkapkan oleh Pendasihat Dukuh Tegalmulyo, Desa Kepek, Wonosari, Gunungkidur sebagai berikut:

"Masyarakat Kepek merasa butuh dengan adanya rasulan ini, sehingga mereka selalu berusaha mengadakan rasulan hingga saat kini. Rasulan dianggap sebagai event sebagai tanda rasa syukur mereka terhadap Tuhannya. Rasulan sendiri sebenarnya bukan hanya untuk umat islam saja. Semua umat beragama yang ada di Kepek ikut melaksanakan rasulan.(Mardiyanto/9/September/ 2017)".

Selain itu, dalam rangkaian tradisi Rasulan, akan dijumpai gunungangununngan yang berisi hasil panen masyarakat. Terdapat filosofi yang terkandung dalam gunungan ini, yaitu memandang ke arah atas untuk selalu bersyukur kepada Tuhan Yang Maha Kuasa. Seperti yang dijelaskan oleh Kepala Dukuh Tegalmulyo, Kepek, Wonosari:

“Gunungan itu menghadap ke atas dan mengerucut karena menggambarkan masyarakat itu diciptakan berbeda-beda. Seperti isi gunungan yang berbeda-beda, ada terong, cabai, tomat, sawi, dan lain-lain. Jadi tetap jadi satu dan menghadap kepada yang Kuasa utuk bersyukur (Sulasto/5/Agustus/2017)”. 


\section{DISKUSI}

Selain dari meriahnya tradisi Rauslan, terdapat nilai-nilai yang diajarkan dari adanya tradisi Rasulan. Nilai-nilai ini disimbolkan dalam beberapa rangkaian kegiatan yang sudah ada sejak dulu. Masyarakat berharap dengan adanya pelaksanaan Rasulan memberikan contoh nilai-nilai yang dapat dipraktikkan dalam kehidupan masingmasing bermasyarakat.

Telah dijelaskan sebelumnya bahwa pendidikan tidak hanya terjadi pada sekolah atau formal saja, melainkan terjadi pula pengajaran yang dilakukan dalam lingkup masyarakat, keluarga atau teman sebaya. Dalam hal ini, sosialisasi menjadi hal penting dalam rangka penguatan nilai budi pekerti. Adanya sosialisasi yang dilakukan dalam berbagai media memberikan pengaruh kepada karakter masyarakat. Pendidikan karakter merupakan bentuk kegiatan manusia yang di dalamnya terdapat suatu tindakan yang mendidik dan diperuntukkan bagi generasi selanjutnya. Tujuan pendidikan karakter adalah untuk membentuk penyempurnaan diri individu secara terusmenerus dan melatih kemampuan diri demi menuju ke arah hidup yang lebih baik. (Kusuma, 2007:3-5).

Masyarakat tidak lepas dari kebudayaan karena masyarakat merupakan dua hal yang tidak dapat dipisahkan. Dalam kehidupannya masyarakat akan menghasilkan suatu kebudayaan. Sehingga tidak ada masyarakat yang tidak memiliki kebudayaan dan sebaliknya tidak ada kebudayaan yang tidak dimiliki masyarakat. Masyarakat memiliki peran sebagai pendukung dan wadah keberadaan kebudayaan. Kebudayaankebudayaan tersebut dilaksanakan secara berkelanjutan dengan tujuan untuk melestarikannya. Hal ini penting dilakukan mengingat adanya kesesuaian adat yang diatur dalam Undang-Undang Nomor 6 Tahun 2014 tentang Desa. Meskipun demikian, adanya perkembangan zaman yang meliputi berbagai bidang menjadi faktor terjadinya perubahan dalam masyarakat. Sehingga dalam suatu kebudayaan tidak akan lepas dari adanya pengaruh perubahan dalam masyarakat.

Kebudayaan berasal dari kata sansekerta Budhayah, ialah bentuk jamak dari budhi yang berarti "budi" atau 
"akal"/ sehingga kebudayaan dapat diartikan sebagai "hal-hal yang bersangkutan dengan budi dan akal" (Koentjoroningrat, 1984). Sifat hakikat kebudayan antara lain: (1) kebudayaan terwujud dan tersalurkan lewat perilaku manusia, (2) kebudayaan telah ada terlebih dahulu mendahului lahirnya suatu generasi tertentu dan tidak akan mati dengan habisnya usia generasi yang bersangkutan, (3) kebudayaan diperlukan oleh manusia dan diwujudkan tingkah lakunya, (4) kebudayaan mencakup aturan-aturan yang berisikan kewajibankewajiban, (5) tindakan-tindakan yang diterima dan ditolak, tindakan-tindakan yang dilarang dan tindakan-tindakan yang diizinkan (Soekanto, 2013: 160).

Pelaksanaan tradisi Rasulan tetap diadakan karena adanya keinginan masyarakat sebagai akibat proses sosialisasi yang terjadi dalam masyarakat itu sendiri. Sosialisasi yang dimaksud adalah pewarisan kebudayaan dari generasi sebelumnya kepada generasi selanjutnya. Awalnya, pewarisan yang ada dalam masyarakat itu sendiri terjadi pada agen sosial yaitu keluarga. Setiap keluarga mensosialisasi anak-anaknya sesuai dengan kebudayaan masyarakat
(Dwiningrum, 201). Lebih luas dari keluarga, teman sebaya, lingkungan masyarakat, media massa, pemerintah, serta lembaga pendidikan memberi kontribusi pula pada proses sosialisasi tradisi Rasulan pada individu.

Dalam tradisi rasulan terkandung nilai-nilai budi pekerti yang dapat dipraktikkan oleh setiap individu. Nilainilai budi pekerti diwariskan kepada individu dalam masyarakat. Keluarga di Gunungkidul, khususnya desa dan dusun terkait selalu mengajarkan anaknya untuk berbagi dengan menyuruh mengundang teman-temannya untuk makan di rumahnya. Kemudian pembagian tugas dan peran dalam pelaksanaan tradisi rasulan juga memberikan nilai-nilai yang dapat diterapkan dalam kehidupannya. Sehingga nilai budi pekerti yang dapat diperoleh adalah tanggung jawab, keikhlasan, toleransi, dan peduli terhadap sesama. Penguatan nilai-nilai budi pekerti tersebut diperoleh melalui serangkaian tradisi rasulan. Masyarakat dan anak-anak yang ikut serta dalam rangkaian kegiatan tradisi rasulan diharapkan dapat menerima nilai-nilai budi pekerti tersebut yang selanjutnya dapat dipraktikkan dalam kehidupan sehari-hari. 
Terdapat banyak nilai-nilai yang terkandung dalam tradisi Rasulan. Diantaranya nilai keikhlasan, gotong royong, tanggung jawab, rasa syukur, toleransi, dan rasa peduli terhadap sesama. Penguatan nilai-nilai budi pekerti tersebut diajarkan memalui beberapa media, misalnya adalah melalui keluarga, pemerintah, sekolah, maupun masyarakat sekitar. Keluarga sebagai tempat pertama individu bersosialisasi. Dalam hal ini, keluarga memiliki peran utama dalam mensosialisasikan nilai-nilai yang terkandung dalam tradisi rasulan kepada anak-anaknya.

Keluarga merupakan kelompok terkecil di masyarakat sebagai tempat pertama kali individu memperoleh pembelajaran atau pewarisan nilai. Nilainilai dasar telah diajarkan pada lingkungan keluarga. Hal ini dilakukan untuk mempersiapkan individu tersebut agar dapat diterima dan mampu hidup di lingkungan masyarakat. Penguatan nilai yang terkait dengan nilai-nilai dalam tradisi Rasulan juga di ajarkan oleh keluarga. Ketika diadakan Rasulan, setiap keluarga menyediakan berbagai makanan untuk dihidangkan kepada tamu yang datang. Melalui tradisi rasulan keluarga mengajarkan kepada anak-anaknya untuk berbagi dengan mengundang temantemannya dan makan bersama di rumahnya. Selain itu, keluarga juga mengajarkan tanggung jawab kepada anak-anaknya untuk melaksanakan tugasnya baik sebagai anggota keluarga maupun anggota msyarakat. Diberikan peran tertentu sehingga anak memiliki rasa tanggung jawab atau kesadaran untuk melaksanakan dan mengikuti tradisi rasulan sebagai ungkapan rasa syukur kepada Tuhan atas segala nikmat yang telah diberikan.

Teman sebaya menjadi salah satu sosialisasi yang cukup dekat ketika individu mulai keluar dan berinteraksi dengan masyarakat luar. Dengan adanya kebiasaan berbagi makanan ketika dilaksanakan Rasulan, terdapat penguatan nilai mengenai keikhlasan dan peduli dengan sesama. Mengundang dan mempersilahkan tamu untuk makan hidangan yang telah disediakan oleh setiap keluarga, mengajarkan individu tersebut untuk ikhlas dan peduli.

Selain itu lingkungan masyarakat, media massa, pemerintah, serta lembaga pendidikan memberi kontribusi pula pada proses sosialisasi tradisi Rasulan pada 
individu. Pada lingkungan masyarakat terdapat solidaritas yang tercipta dengan adanya kesadaran yang sama mengenai tradisi Rasulan yang harus terus dilestarikan. Misalnya adalah gotong royong, yang berarti bersama-sama mengerjakan sesuatu atau membuat sesuatu untuk mencapai suatu hasil. Budaya gotong royong dilandasi oleh manusia terkait dengan lingkungan sosialnya, manusia sebagai makhluk sosial, manusia perlu menjaga baik dan selaras dengan sesamanya, manusia perlu menyesuaikan diri dengan anggota masyarakatnya (Mixdam, 2015: 75). Tradisi rasulan yang setiap tahunnya diadakan dapat terlaksana karena dilakukan bersama-sama. Mulai dari persiapan sampai pelaksanaan rangkaian kegiatan rasulan masyarakat saling bekerjasama melaksanakan tradisi rasulan. Terdapat berbagai pihak yang terlibat dalam kegiatan rasulan diantaranya warga masyarakat, pemudapemudi karang taruna, pemerintah yang saling bergotong royong dan mendukung untuk mensukseskan kegiatan tradisi rasulan.

Kemudian nilai toleransi yaitu sikap saling menghargai perbedaan-perbedaan yang ada. Dalam tradisi Rasulan sikap toleransi antar masyarakat itu diwujudkan dalam pelaksanaan tradisi rasulan, bahwa tradisi rasulan itu diikuti oleh semua umat beragama. Seperti yang terdapat di Desa Kepek, Wonosari, Gunungkidul, tradisi rasulan dilaksanakan oleh seluruh warga masyarakat dari latar belakang agama yang berbeda. Seperti umat Islam mengadakan pengajian yang dilaksanakan sebelum kegiatan tradisi rasulan. Kemudian bagi umat beragama lain diberikan waktu atau kesempatan untuk mengadakan renungan. Hal tersebut merupakan sikap toleransi masyarakat. Masyarakat saling menghormati perbedaan diantara mereka dengan memberikan kesempatan bagi masyarakat lainnya untuk melaksanakan kegiatan sesuai dengan agamanya. Sehingga pelaksanaan tradisi Rasulan menjadi tali pengikat masyarakat yang memiliki berbagai perbedaan karena Rasulan tidak dimiliki oleh umat Islam saja, melainkan milik masyarakat yang beragama lain juga.

Selain itu, nilai lain yang terkandung dan diajarkan dalam tradisi rasulan adalah keikhlasan. Keikhlasan merupakan suatu bentuk dari perwujudan 
tindakan yang dilakukan oleh individu atau masyarakat dengan dilandasi hati nurani tanpa mengeluh ataupun meminta imbalan dalam melakukan tindakannya (Mixdam, 2015: 76). Dalam tradisi rasulan diajarkan nilai keikhlasan diantaranya masyarakat ikhlas memberikan waktu, tenaga, dan rezekinya untuk pelaksanaan tradisi rasulan. Mereka meluangkan waktunya untuk mengikuti rangkaian tradisi rasulan. Kemudian memberikan tenaganya dalam kegiatan rasulan mulai dari persiapan, membuat gunungan, mengikuti kirab, dan pementasan kesenian tanpa meminta imbalan. Selain itu, masyarakat juga memberikan sumbangan yaitu iuran untuk kegiatan rasulan dan setiap rumah menyediakan makanan. Hal tersebut merupakan bentuk keikhlasan masyarakat dalam tradisi rasulan.

Berdasarkan perkembangan yang ada dalam masyarakat, meskipun sudah termasuk masyarakat yang modern, tradisi Rasulan masih dipegang kuat oleh masyarakat Gunungkidul, khususnya di Desa Kepek, Wonosari dan Dusun Jambu, Plajan, Saptosari. Terdapat nilai dasar yang menjadi dasar perilaku masyarakat setempat. Moerdiono, melalui
Ruyadi (2010) menjelaskan bahwa nilai dasar merupakan asas-asas sebagai dalil yang tidak dipertanyakan lagi dan nilai instrumental merupakan pelaksanaan nilai dasar yang bersifat dinamis dan kontekstual. Awalnya masyarakat mengadakan tradisi Rasulan diperuntukkan untuk warga petani atau karena merasa diberi keselamatan. Sehingga masyarakat melanjutkan tradisi Rasulan dengan tujuan bersyukur kepada Tuhan Yang Maha Kuasa.

Nilai-nilai budi pekerti disampaikan melalui berbagai media. Sebagai khasnya adalah diadakannya gunungan yang berisi hasil bumi. Gunungan tersebut berbentuk kerucut dengan runcing ke atas. Hal ini menggambarkan bahwa sebagai ciptaan Tuhan yang tercipta dengan berbagai perbedaan, harus berpandangan secara vertikal yang berarti selalu mengingat Tuhan dan bersyukur kepada Tuhan.

Dari gunungan tersebut dijelaskan bahwa perlu pemahaman pada masyarakat bahwa meskipun diciptakan dengan berbagaai karakter, agama, dan bahasa harus bersatu dan bekerjasama untuk senantiasa bersyukur kepada Tuhan. Menjalankan kehidupan dengan kerukunan juga perlu ditekankan 
bersama. Sehingga nilai yang terkandung dalam salah satu perlengkapan pada tradisi Rasulan dapat tersampaikan dan dipahami oleh masyarakat.

Sehingga di tengah arus modernisasi yang semakin populer ini, penguatan nilai budi pekerti perlu dipupuk dan dikembangkan sesuai dengan perkembangan zaman dengan tanpa menghilangkan tradisi yang ada. Seperti halnya yang ada di Gunungkidul tersebut, penguatan nilai budi pekerti melalui tradisi Rasulan dan terdapat beberapa modifikasi namun tetap memiliki esensi tradisinya. Tidak terlepas dari pendidikan, tradisi Rasulan tersebut merupakan salah satu upaya dalam penguatan nilai budi pekerti. Sumber nilai budi pekerti yang dimaksud berasal dari para sesepuh yang masih melestarikan tradisi Rasulan dengan mempertahankan nilai-nilai tradisional dan budi pekertinya. Selanjutnya diinovasi oleh generasi penerusnya tanpa menghilangkan nilai yang terkandung.

Sesuai dengan yang diungkapkan sebelumnya bahwa pendidikan memiliki fungsi manifes (nyata) yaitu mengembangkan bakat perseorangan demi kepuasan pribadi dan untuk kepentingan masyarakat. Kepentingan masyarakat diantaranya untuk melestarikan kebudayaan yang ada di masyarakat tersebut karena pendidikan akan mengubah pola pikir masyarakat untuk tetap menjaga dan melestarikan kebudayaan yang dimilikinya. Maka melalui pendidikan, masyarakat dapat lebih memahami mengenai pentingnya menjaga dan melestarikan tradisi kebudayan yang ada yaitu seperti tradisi rasulan yang dilaksanakan masyarakat Gunungkidul. Tradisi rasulan yang memiliki nilai-nilai budi pekerti tersebut perlu dijaga dan dilestarikan oleh masyarakatnya. Dengan tradisi rasulan yang tetap terjaga dan lestari hingga dimasa yang akan datang, maka penguatan nilai-nilai budi pekerti oleh masyarakat melalui tradisi rasulan akan berjalan terus menerus. Sehingga masyarakat memahami nilai-nilai tersebut dan menjadikan masyarakat memiliki karakter kepribadian budi pekerti yang baik.

Telah dijelaskan bahwa pada hakikatnya, pendidikan karakter merupakan suatu sistem pendidikan yang berupaya menanamkan nilai-nilai luhur kepada warga sekolah yang meliputi 
komponen pengetahuan, kesadaran atau kemauan, dan tindakan untuk melaksanakan nilai-nilai tersebut. Dalam membangun karakter budaya bangsa, lingkungan pendidikan harus mengarah pada penciptaan lingkungan keluarga yang sarat dengan nilai (agama, budaya, dan kebangsaan). Dengan pendidikan karakter melalui tradisi rasulan, keluarga dan masyarakat dapat menanamkan nilainilai budi pekerti seperti gotong royong, keikhlasan, tanggung jawab, toleransi, kepedulian kepada generasi selanjunya. Kemudian nilai-nilai tersebut dapat dipahami dan dilaksanakan dalam kehidupan sehari-hari. Sehingga dapat membentuk karakter masyarakat yang berbudi pekerti luhur.

\section{KESIMPULAN}

Tradisi rasulan dilaksanakan hampir di seluruh wilayah Gunungkidul. Namun memiliki latar belakang yang berbedabeda di setiap tempat pelaksanaannya. Meskipun demikian, masing-masing pelaksanaannya memiliki tujuan yang sama yaitu sebagai sarana untuk mengekspresikan rasa syukur kepada Tuhan atas segala nikmat yang telah diberikan selama satu tahun ini.

Dalam tradisi Rasulan terkandung nilai-nilai budi pekerti yang dapat dipraktikkan oleh setiap individu di kehidupan masyarakat. Nilai-nilai tersebut antara lain adalah tanggung jawab, rasa syukur, keikhlasan, gotong royong, toleransi, dan kepedulian antar sesama. Nilai budi pekerti diwariskan kepada individu dalam masyarakat melalui sosialisasi. Sosialisasi menjadi hal yang penting untuk penguatan nilai budi pekerti dalam masyarakat melalui tradisi Rasulan. Penguatan nilai budi pekerti tersebut diajarkan melalui beberapa media, seperti keluarga, sekolah, pemerintah, dan masyarakat sekitar. Adanya media sosialisasi yang dilakukan dalam berbagai media memberikan pengaruh kepada karakter masyarakat. 


\section{DAFTAR PUSTAKA}

A., Depict Pristine dan Suryani, Endang, (2015), Implementasi Pembentukan Karakter Budi Pekerti di SMP Negeri 1 Tanggul Jember. Jurnal Pendidikan Karakter, Tahun V. No. 1, April 2015

Dwiningrum, Siti Irene Astuti. 2016. Pendidikan Sosial Budaya. Yogyakarta: UNY Press

Koentjoroningrat. 2009. Pengantar Ilmu Antropologi. Jakarta: Rineka Cipta

Mixdam dan Hidayah. 2015. Sosialisasi Adat Rasulan di Kalangan Anak-anak pada Era Modernisasi di Daerah Playen Gunungkidul. Jurnal Pendidikan Sosialisasi

Mixdam, Candra Bagus Sultan. 2015. Sosialisasi Adat Rasulan di Kalangan Anak-anak Pada Era Modernisasi di Daerah Playen Gunungkidul. Skripsi. FIS, Pendidikan Sosiologi, Universitas Negeri Yogyakarta

Puspitasari, R., Hastuti D., Herawati, T., (2015), Pengaruh Pola Asuh Disiplin dan Pola Asuh Spiritual Ibu terhadap Karakter Anak Usia Sekolah Dasar. Jurnal Pendidikan Karakter, Tahun V No. 2 Oktober 2015

Ruyadi, Yudi. (2010). Model Pendidikan Karakter Berdasarkan Budaya Lokal. Proceding of The $4^{\text {th }}$ International Conference on Teacher Education, November, Bandung

Soekanto, Soerjono. 2013. Sosiologi Suatu Pengantar. Jakarta: Rajawali Pers

Supraptiningrum dan Agustini, (2015), Membangun Karakter Siswa melalui Budaya Sekolah di Sekolah Dasar. Jurnal Pendidikan Karakter, Tahun V No. 2 Oktober 2015 